\title{
Norepinephrine, tri-iodothyronine and insulin upregulate glyceraldehyde-3-phosphate dehydrogenase mRNA during brown adipocyte differentiation
}

Isabel Barroso, Begoña Benito, Custodia García-Jiménez, Arturo Hernández, María Jesús Obregón and Pilar Santisteban

Instituto de Investigaciones Biomédicas 'Alberto Sols', Consejo Superior de Investigaciones Científicas, Universidad Autónoma de Madrid, Arturo Duperier 4, E-28029-Madrid, Spain

(Correspondence should be addressed to P Santisteban, Instituto de Investigaciones Biomédicas, CSIC/UAM, Arturo Duperier 4, 28029-Madrid, Spain; Email: psantisteban@iib.uam.es)

\begin{abstract}
Glyceraldehyde-3-phosphate dehydrogenase $(G A P D H)$ gene expression was studied in differentiating brown adipocytes. Northern blot analysis showed that GAPDH mRNA levels increased during differentiation of precursor cells into mature adipocytes, mainly in the initial stages of the differentiation process. Insulin, tri-iodothyronine $\left(\mathrm{T}_{3}\right)$ and norepinephrine, the main regulators of brown adipose tissue function, upregulated GAPDH mRNA levels, whereas retinoic acid inhibited them. The effect of insulin was present on all culture days examined, was time- and dose-dependent, and was exerted through its own receptors, as demonstrated by comparing insulin and insulin-like growth factor (IGF)-I and -II potencies in this system. Using the transcriptional inhibitor, actinomycin D, we demonstrated that $\mathrm{T}_{3}$, and to a lesser extent insulin, stabilized GAPDH mRNA. Experiments with cycloheximide indicated that both hormones require de novo protein synthesis to achieve their effects. Using cAMP analogs, we showed that the effect of norepinephrine is probably exerted through this second messenger. Co-operation was elucidated between norepinephrine- and insulin-mediated induction of GAPDH mRNA levels. In summary, we have demonstrated that GAPDH mRNA is subjected to multifactorial regulation in differentiating brown adipocytes that includes differentiation of precursor cells and the lipogenic/lipolytic regulators of the tissue.
\end{abstract}

European Journal of Endocrinology 141 169-179

\section{Introduction}

Glyceraldehyde-3-phosphate dehydrogenase (GAPDH) (EC 1.2.1.12) was first discovered as an abundant, glycolytic enzyme that catalyzes the conversion of glyceraldehyde 3-phosphate to 1,3-diphosphoglycerate. Recent evidence demonstrated that GAPDH also participates in many other cellular processes (1). Although this enzyme has been, for some years, considered to be a non-regulated protein, expression of the GAPDH gene varies in different circumstances such as hypoxia (2), transition during the cell cycle (3), or exposure to the toxic compound, tetrachlorodibenzo-p-dioxin (TCDD) (4). The changes observed in response to insulin, serum, or epidermal growth factor have led investigators to question the use of GAPDH as a suitable control in gene regulation studies (5). More recently, other agents such as vitamin $\mathrm{D}_{3}(6)$ or glucose (7) have been added to the growing list of GAPDH gene regulators. However, transcription factors that activate the GAPDH gene promoter remain obscure, with the exception of a protein that mediates the insulin response $(8,9)$. In adipose tissue, GAPDH is the rate-limiting enzyme for providing lipogenic substrates in the glycolytic pathway. Spiegelman \& Green demonstrated the GAPDH protein levels increase during adipose differentiation (10). Finally, GAPDH gene expression is upregulated in a model of genetically obese rats (11).

Brown adipose tissue (BAT) provides heat in facultative thermogenesis, and participates in the regulation of the energy balance in the body. In so doing, BAT accounts for the expression of the tissue-specific uncoupling protein 1 (UCP 1) that dissipates energy by uncoupling oxidative phosphorylation (12). Two other uncoupling proteins, UCP 2 and UCP 3, which have a wider tissular expression, have recently been cloned (13-15). BAT is subjected to a complex neurohormonal regulation, exerted initially by the sympathetic nervous system (SNS) $(16,17)$ and thyroid hormones (18). Insulin (19) and retinoids (20) have also been identified as important regulators of brown adipocyte function. This tissue is closely linked to glucose/lipid metabolism, as demonstrated by three lines of evidence. First, glucose and fatty acids are the 
energy sources of BAT (21). Secondly, as fatty acids are the main energy source of BAT, lipid metabolism is essential in brown adipocytes; in these cells, both lipogenesis and lipolysis are active, and the balance between them is carefully maintained by an accurate regulation of lipogenesis- and lipolysis-related enzymes (22). Thirdly, BAT ablation results in obesity and general metabolic disorders (23). For these reasons, brown adipocytes constitute an excellent model with which to study the regulation of enzymes related to lipid metabolism.

We have chosen primary cultures of brown preadipocytes with the capacity to differentiate, in culture, into mature adipocytes. These cultures offer the advantage of working in a defined medium, in which it is possible to study the function of a single factor. In addition, they are subjected to the same regulators that are effective in vivo, and their results are easier to interpret, as secondary effects and tissue or blood-borne interactions are not present. Before reaching confluence, precursor cells have the morphology of mesenchymal-type cells. Once confluent, the preadipocytes differentiate into mature cells: they accumulate lipids in the cytosol, acquire the morphology typical of adipocytes, and become responsive to hormones that regulate lipid metabolism (24). The acquisition of the BAT phenotype in these cells is reflected by the expression of the differentiation marker, UCP $1(25,26)$.

In the present report, we show that GAPDH mRNA levels increase in parallel with brown adipocyte differentiation. A physiological dose of insulin induces GAPDH transcript on whichever culture day it is added. Tri-iodothyronine $\left(\mathrm{T}_{3}\right)$, another key regulator of BAT function, also upregulates GAPDH mRNA in this
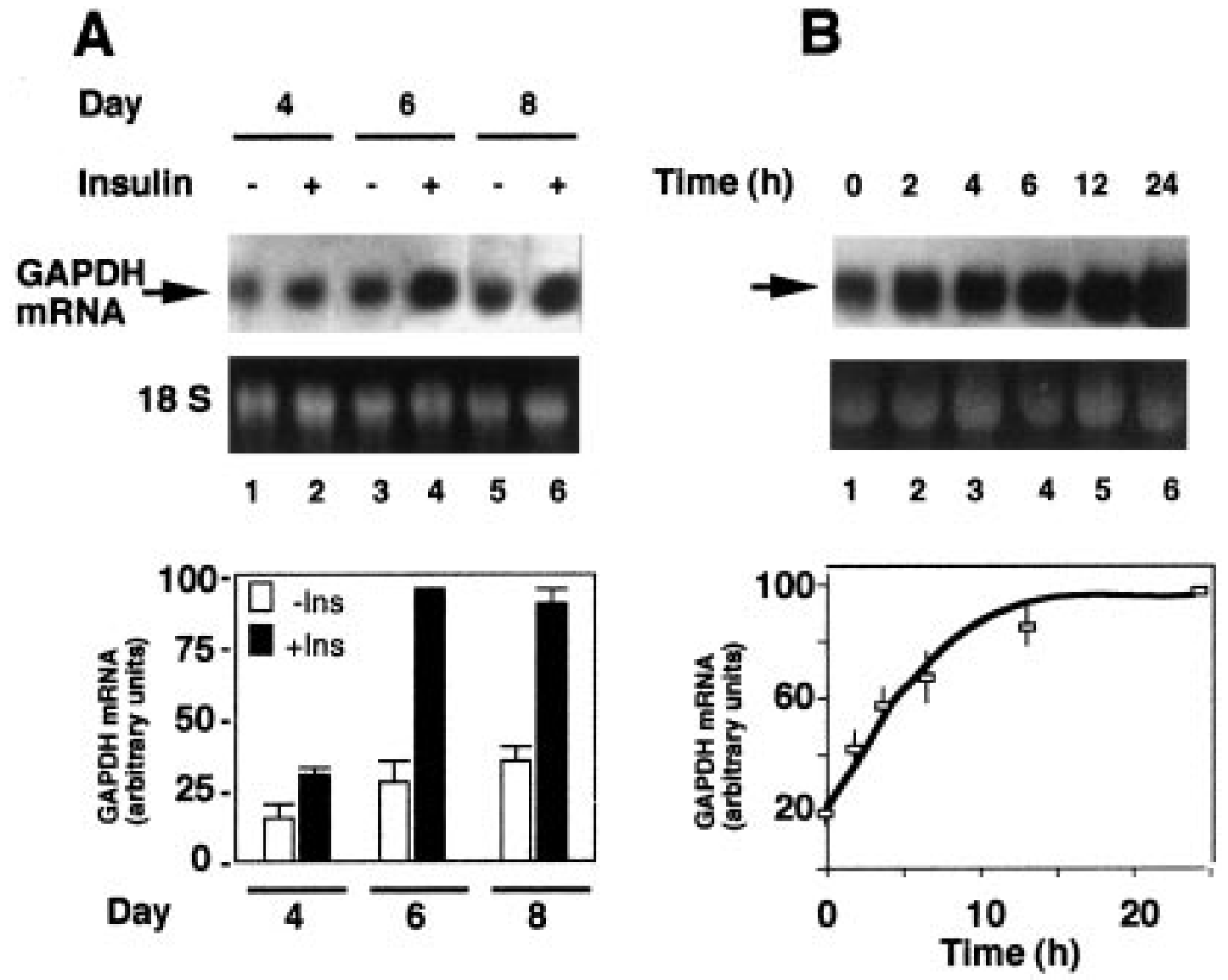

Figure 1 GAPDH mRNA levels during brown preadipocyte differentiation: effect of insulin. (A) Preadipocytes were grown and differentiated into mature adipocytes as described in Materials and methods, and total RNA was extracted at the days indicated in the figure, which represent different stages of the differentiation process: day 4, preadipocytes; day 6, differentiating adipocytes; day 8, mature adipocytes. Half of the plates (+) received $4 \mathrm{nmol} / \mathrm{l}$ insulin for the last $24 \mathrm{~h}$; the remaining plates (-) were incubated in the absence of insulin for the last $24 \mathrm{~h}$. A representative Northern blot hybridized with the GAPDH probe and the corresponding ethidium bromide staining are shown. The graph represents the quantitation of GAPDH mRNA levels by densitometric analysis. Data are given as the mean \pm S.D. from three independent experiments. Ins, insulin. (B) Brown adipocytes at day 7 after seeding were maintained in insulin-depleted medium for $24 \mathrm{~h}$ and then stimulated with $40 \mathrm{nmol} / /$ insulin and total RNA was extracted at the times indicated. A representative Northern blot hybridized with the GAPDH probe, together with the ethidium bromide staining of the gel are shown. Densitometric quantitation was obtained; the mean \pm S.D. from three different experiments are represented. 
system. Both hormones require de novo protein synthesis and their effects are due, in part, to the stabilization of GAPDH transcripts. Norepinephrine, the main regulator of BAT function, also induces GAPDH gene expression, and could be acting through the cAMP signaling pathway, as cAMP analogs reproduce the induction obtained with norepinephrine. Finally, when norepinephrine, insulin and $\mathrm{T}_{3}$ were added together in different combinations, an apparent co-operation between norepinephrine and insulin, but not $T_{3}$, was observed. Overall, our data demonstrate that GAPDH mRNA increases concomitantly with brown adipocyte differentiation and exhibits a multifactorial control in this culture system.

\section{Materials and methods}

\section{Materials}

Tissue culture media were purchased from Gibco (Uxbridge, England), and newborn calf serum was from Flow (Paisley, Scotland). Guanidine HCl, 3-(Nmorpholino) propanesulfonic acid (MOPS), insulin, $\mathrm{T}_{3}$, norepinephrine, 8-Br-cAMP, all-trans retinoic acid, cycloheximide and actinomycin $\mathrm{D}$ were provided by Sigma (St Louis, MO, USA). Insulin-like growth factors (IGFs)-I and -II were obtained from Amgen (Thousands Oaks, CA, USA). Nytran membranes were from Schleicher and Schuell (Keene, NH, USA) and the random primer kit was Pharmacia (Uppsala, Sweden). $\left[\alpha_{-}{ }^{32} \mathrm{P}\right] \mathrm{dCTP}$ was purchased from ICN (Irvine, CA, USA, and X-Omat radiographic films from Kodak (Rochester, NY, USA).

\section{Cell isolation and culture}

Precursor cells were obtained from interscapular brown adipose tissue of 20-day-old rats as described previously (24), but a hypo-osmotic shock was not administered. After collagenase digestion, and separation of mature adipocytes by flotation and filtration, precursor cells were obtained by centrifugation. Precursor cells obtained from the same animal were divided between two culture flasks $\left(25 \mathrm{~cm}^{2}\right.$; Nunclonc, Nunc, Kamstrup, Denmark) containing $5 \mathrm{ml}$ DMEM medium supplemented with $10 \%$ newborn calf serum, $4 \mathrm{nmol} / \mathrm{l}$ insulin, $10 \mathrm{mmol} / \mathrm{l} \mathrm{HEPES}, 15 \mathrm{mmol} / \mathrm{l}$ sodium ascorbate, $50 \mathrm{IU}$ penicillin, and $50 \mathrm{mg} / \mathrm{ml}$ streptomycin, and grown at $37^{\circ} \mathrm{C}$ in an atmosphere of $5 \% \mathrm{CO}_{2}$ and $95 \%$ humidity. Insulin was omitted in the experiments with insulin, IGF-I or IGF-II. Cells were washed on day 1 , and the culture medium was changed on days $1,3,5$ and 7 after seeding. During this period, cells proliferate until they reach confluence (days 4-5) and differentiate thereafter (days 5-9). The differentiation process was monitored by accumulation of lipid droplets in the cytosol. Experiments were performed during differentiation (4-9 days after seeding). Cells were exposed to insulin,
$\mathrm{T}_{3}$, norepinephrine, 8-Br-cAMP, or all-trans retinoic acid at the concentrations and times indicated for each experiment. In some experiments, cells were grown in hypothyroid medium, which was obtained by treatment of serum with resin Dowex AG1X8 (Bio-Rad, Richmond, CA, USA). Other experiments were carried out with cells growing in a medium depleted of most growth factors and hormones, which was obtained by additional treatment of serum with charcoal (27). When indicated, cycloheximide and actinomycin D were used in doses of $5 \mu \mathrm{g} / \mathrm{ml}$. The day indicated in the figures represents the day of harvesting.

\section{RNA extraction and Northern blot analysis}

At the termination of the experiments, total RNA was isolated by treatment of the cells with hot guanidine $\mathrm{HCl}$ extraction buffer (28). Samples of $25 \mu \mathrm{g}$ total RNA were electrophoresed in 1\% agarose gels containing $2.2 \mathrm{~mol} / \mathrm{l}$ formaldehyde. RNA was blotted on nylon filters (Nytran, Schleicher and Schuell), following the manufacturer's recommendations. Hybridization and washing steps were carried out as described elsewhere (29). A $1.0 \mathrm{~kb}$ Pst I fragment obtained from a human GAPDH cDNA (8) was used as probe. It hybridizes specifically with a unique $1.3 \mathrm{~kb}$ mRNA. The GAPDH probe was labeled by random oligopriming to a specific activity of $1 \times 10^{9}$ c.p.m. $/ \mu \mathrm{g}$ DNA. Ethidium bromide staining of ribosomal $18 \mathrm{~S}$ was used to correct for variations in sample loading: the levels of GAPDH mRNA were visualized by autoradiography, quantitated by densitometric scanning, and corrected by the corresponding densitometric value of ribosomal 18S. The results are expressed as an intensity percentage compared with the maximum expression of each experiment. Each value represents the mean \pm s.D. of three independent experiments.

\section{Results}

\section{GAPDH gene expression is activated during brown adipocyte differentiation. Effect of insulin}

After 4-5 days in culture, preadipocytes reach confluence and begin to express the marker of brown adipocyte differentiation, UCP 1 (26). From that day on, lipogenic differentiation begins, as we observed by lipid accumulation in the cytosol (data not shown), and cells are fully differentiated by days $7-8$. We first studied whether the differentiation process affected GAPDH mRNA levels. To demonstrate this, precursor cells were differentiated in the absence of insulin, a known regulator of the GAPDH gene in other systems, and GAPDH mRNA levels were analyzed (Fig. 1A). As shown in this figure, GAPDH transcript was already detectable in brown preadipocytes (day 4). A low, but reproducible increase in GAPDH mRNA levels was 

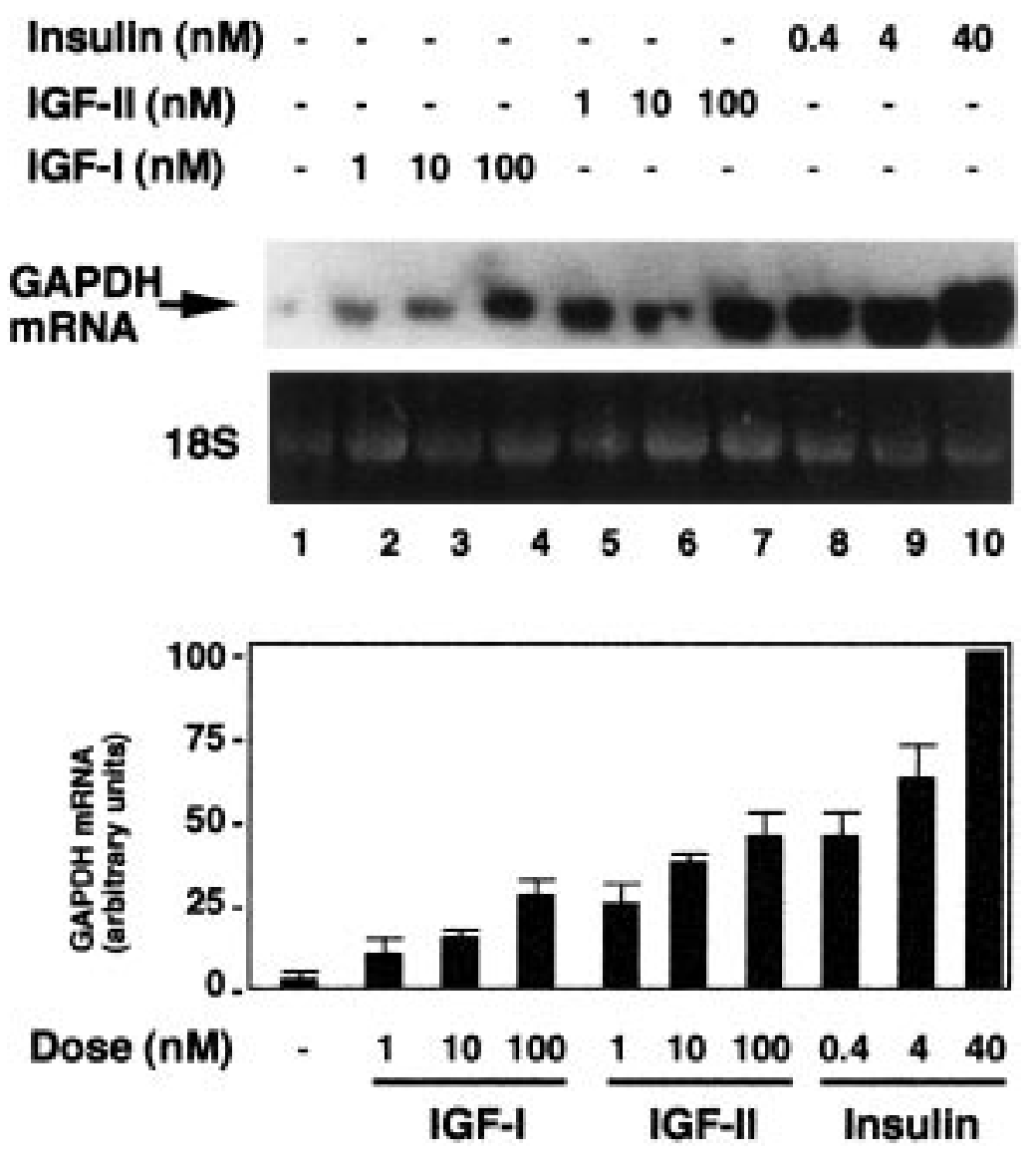

Figure 2 The effect of insulin is dosedependent and takes place through its own receptor. Cells at day 7 after seeding were grown in the absence of insulin for $24 \mathrm{~h}$ and then incubated with sub-, physiological or supra-physiological doses of insulin, IGF-I or IGF-II for a further $24 \mathrm{~h}$. Total RNA was prepared and hybridized with a specific probe for GAPDH. A representative Northern blot is shown, and the ethidium bromide staining control. GAPDH mRNA levels were quantitated by densitometry of three independent autoradiograms and data are represented as mean \pm S.D.

detected in the early stages of lipogenic differentiation (from days 4 to 6), with no other significant change in the latest phases of differentiation (days 6 to 8). This early onset of GAPDH transcript during lipogenic activation is in agreement with similar results obtained in white adipose tissue (30).

Insulin has a key role in adipose cells, where it activates differentiation by triggering lipogenesis (19). In addition, it regulates GAPDH gene expression in a variety of systems $(31,32)$, including white adipocytes $(8,11)$. GAPDH regulation in differentiating brown adipocytes was studied in the presence and absence of insulin, to discriminate the effect due to insulin from that due to the differentiation process. Figure 1A shows that insulin (black bars) induced GAPDH mRNA levels on all culture days examined, indicating that its effect on GAPDH was direct and not a consequence of activated differentiation.

The effect of insulin was time-dependent (Fig. 1B). Cells at day 7 after seeding were grown in the absence of insulin for $24 \mathrm{~h}$ and then incubated with $4 \mathrm{nmol} / \mathrm{l}$ insulin for the times indicated in the figure. An effect of insulin was already observed within $2 \mathrm{~h}$ of treatment, and then GAPDH mRNA levels increased slowly, reaching a maximum effect by $24 \mathrm{~h}$. Insulin also induced GAPDH transcript in a dose-dependent manner. Cells at day 7 after seeding were depleted of insulin for $24 \mathrm{~h}$ and then treated with $0.4,4$ or $40 \mathrm{nmol} / \mathrm{l}$ insulin for a further $24 \mathrm{~h}$. As may be seen in Fig. 2, insulin induced GAPDH mRNA with the minimum dose used $(0.4 \mathrm{nmol} / \mathrm{l}$, which is a physiological dose for this tissue) (lane 8) and maximum effect was achieved with $40 \mathrm{nmol} / \mathrm{l}$ insulin.

Insulin may exert its effects by acting through its own receptors or by activating IGF-I or IGF-II receptors. To characterize further the insulin regulation of GAPDH in this system, we compared the effects mediated by insulin, IGF-I and IGF-II on GAPDH gene expression. Cells at day 7 after seeding were incubated with insulinfree medium for $24 \mathrm{~h}$ and then treated with sub-, physiological or supra-physiological doses of all three peptides, and GAPDH mRNA levels were analyzed (Fig. 2). Whereas IGF-I and IGF-II in supra-physiological doses $(100 \mathrm{nmol} / \mathrm{l})$ efficiently induced GAPDH, an effect of insulin was observed with all doses used, even with physiological amounts $(0.4 \mathrm{nmol} / \mathrm{l})$. This finding demonstrates that insulin induces GAPDH mRNA in brown adipocytes by activating its own receptors. However, we cannot exclude the possibility that higher doses of insulin could activate IGF receptors, as even the 

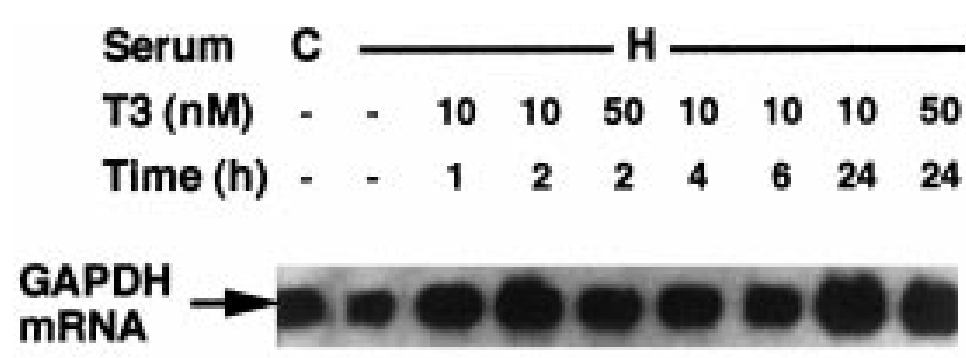

Figure 3 Effect of $T_{3}$ (T3) on GAPDH mRNA. Brown adipocytes at day 6 after seeding were grown either in control $(\mathrm{C})$ medium or maintained for $24 \mathrm{~h}$ in a medium depleted of thyroid hormones $(\mathrm{H})$. Cells were then treated with $10 \mathrm{nmol} / \mathrm{l}$ or $50 \mathrm{nmol} / / \mathrm{T}_{3}$ for the times indicated in the figure. A representative Northern blot, the corresponding ethidium bromide staining and the quantitation of the densitometric scanning from three independent experiments are shown. Data are means \pm S.D.
$18 \mathrm{~S}$

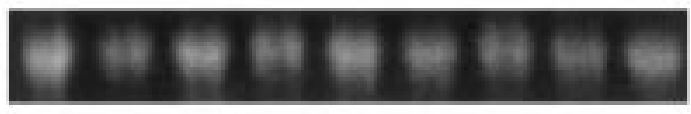

$\begin{array}{lllllllll}1 & 2 & 3 & 4 & 5 & 6 & 7 & 8 & 9\end{array}$

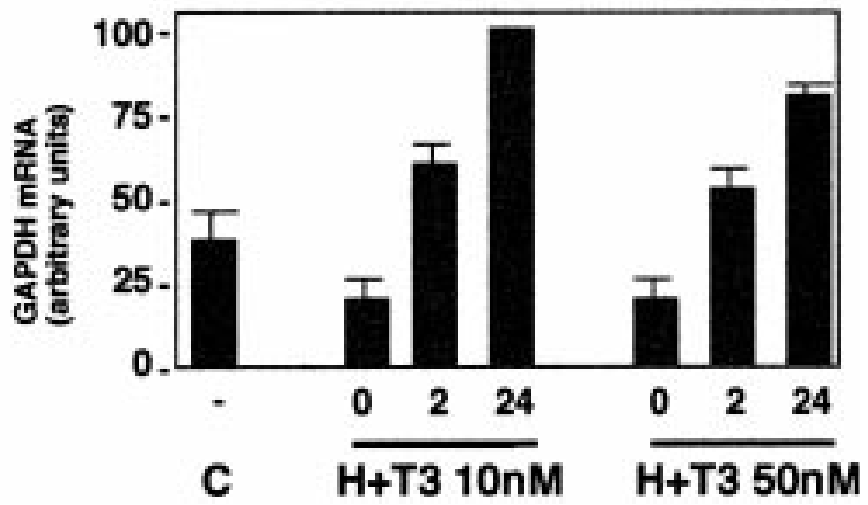

highest dose of insulin tested here $(40 \mathrm{nmol} / \mathrm{l})$ did not attain a plateau effect.

The effect of insulin on GAPDH transcript was seen better during the lipogenic differentiation period (between days 5 and 9), so this was the period examined in subsequent experiments.

\section{$T_{3}$ induction of GAPDH mRNA levels in differentiating brown adipocytes}

Because thyroid hormones are known to be one of the main regulators of BAT function (18) and $\mathrm{T}_{3}$ has been reported to affect gene expression in this tissue (33-35), we investigatedwhether this hormone had any effect on GAPDH mRNA levels in this system. Cells at day 6 after seeding were grown either in control medium or in hypothyroid medium for $24 \mathrm{~h}$. Cells were then treated with 10 or $50 \mathrm{nmol} / \mathrm{l} \mathrm{T}_{3}$ for different times. As shown in Fig. 3, GAPDH mRNA levels were decreased slightly in cells grown in the absence of thyroid hormones (lane 1 compared with lane 2). In these cells, $\mathrm{T}_{3}$ treatment not only fully restored GAPDH expression, but activated it to well above control levels. The maximum effect was achieved with $10 \mathrm{nmol} / \mathrm{l} \mathrm{T}_{3}$ for $24 \mathrm{~h}$, whereas higher doses (such as $50 \mathrm{nmol} / \mathrm{l} \mathrm{T}_{3}$ ) did not increase the response.

\section{$T_{3}$ and insulin stabilize GAPDH mRNA and require de novo protein synthesis}

To examine more closely the mechanism by which insulin and $\mathrm{T}_{3}$ stimulate GAPDH mRNA, we adopted two different approaches. In the first, cells were induced with insulin or $\mathrm{T}_{3}$ in the presence of the inhibitor of transcription, actinomycin D. Cells at day 6 after seeding were induced to achieve maximal induction with optimal doses of $\mathrm{T}_{3}$ or insulin $\left(10 \mathrm{nmol} / \mathrm{l} \mathrm{T}_{3}\right.$ or $40 \mathrm{nmol} / \mathrm{l}$ insulin respectively) for $24 \mathrm{~h}$, and then were treated with $5 \mu \mathrm{g} / \mathrm{ml}$ actinomycin D during the times indicated in Fig. 4. The results obtained show that the half-life of GAPDH mRNA increased from $7 \mathrm{~h}$ to $15 \mathrm{~h}$ in cells stimulated with $\mathrm{T}_{3}$, and to a lesser extent (from $7 \mathrm{~h}$ to $9 \mathrm{~h}$ ) in cells treated with insulin. These data indicate that $\mathrm{T}_{3}$ induces GAPDH mainly through stabilization of its mRNA. With regard to insulin, the observed increase in GAPDH mRNA produced by this hormone was much greater than its effect on the stabilization of GAPDH transcript. This observation suggests a direct effect of insulin on the transcriptional rate of GAPDH, which has already been reported in other systems $(32,36)$.

In the second approach, cells were induced with insulin or $\mathrm{T}_{3}$ in the presence or not of $5 \mu \mathrm{g} / \mathrm{ml}$ 


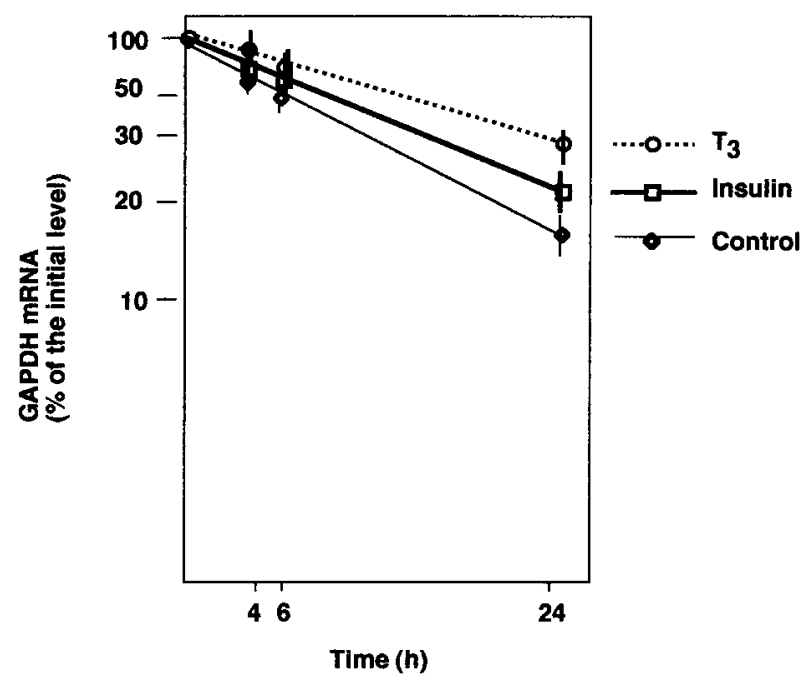

Figure $4 \mathrm{~T}_{3}$ and insulin stabilize GAPDH mRNA. Brown adipocytes at day 6 after seeding were cultured in control medium or in a medium supplemented for the last $24 \mathrm{~h}$ with $40 \mathrm{nmol} / \mathrm{l}$ insulin or $10 \mathrm{nmol} / \mathrm{l} \mathrm{T}_{3}$ to achieve maximal induction of GAPDH mRNA levels (which was taken as $100 \%)$. At this time, actinomycin D $(5 \mu \mathrm{g} / \mathrm{ml})$ was added, total RNA was obtained after 4,6 or $24 \mathrm{~h}$, and Northern blot performed. The logarithmic representation of GAPDH mRNA levels relative to the amount present before actinomycin $D$ treatment is shown. Data are given as means \pm s.D. from three different experiments.

cycloheximide, an inhibitor of de novo protein synthesis. When used, cycloheximide was added 30 min before the hormones. Cells maintained in the absence of thyroid hormones or insulin for $12 \mathrm{~h}$ were incubated at day 5 of differentiation with $10 \mathrm{nmol} / \mathrm{l} \mathrm{T}_{3}$, or at day 6 of differentiation with $40 \mathrm{nmol} / \mathrm{l}$ insulin for a further $12 \mathrm{~h}$. Cycloheximide was able to inhibit the expected induction

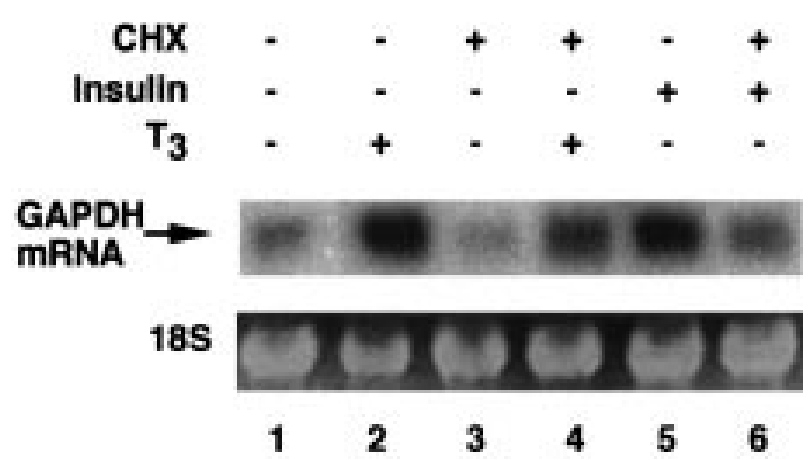

Figure $5 \mathrm{~T}_{3}$ and insulin induction of GAPDH mRNA levels requires de novo protein synthesis. Brown adipocytes were cultured in a medium depleted of insulin or thyroid hormones for $12 \mathrm{~h}$. After this time, cells were treated with $10 \mathrm{nmol} / / \mathrm{T}_{3}$ or $40 \mathrm{nmol} / \mathrm{l}$ insulin for $12 \mathrm{~h}$ in the presence or absence of $5 \mu \mathrm{g} / \mathrm{ml}$ cycloheximide (CHX). When used, $\mathrm{CHX}$ was added $30 \mathrm{~min}$ before the hormones. $\mathrm{T}_{3}$ treatment was performed from days 5 and 6 , and insulin induction between days 6 and 7. Total RNA was obtained and assayed for GAPDH gene expression. A representative Northern blot and the corresponding ethidium bromide staining are shown produced both by $\mathrm{T}_{3}$ (Fig. 5, lanes 2 and 4), and by insulin (lanes 5 and 6 ), indicating that de novo protein synthesis is required in the induction of GAPDH mRNA mediated by both hormones.

\section{Norepinephrine stimulates GAPDH mRNA levels in brown adipocytes}

Norepinephrine, released at the SNS terminals, is considered to be the main regulator of BAT thermogenic function (16). After adrenergic stimulation, norepinephrine triggers lipolysis and thermogenesis in brown adipocytes $(16,26)$. A cross-talk between norepinephrine and $\mathrm{T}_{3}$ pathways in this tissue has been extensively reported (37-39). In addition, there is a classical antagonism between norepinephrine and insulin actions, norepinephrine being considered as a lipolytic enzyme and insulin as a lipogenic one (40). To study the effect of norepinephrine, in addition to its possible interactions with insulin, $\mathrm{T}_{3}$, or both, cells at day 6 (in the case of insulin), or at day 7 (for $\mathrm{T}_{3}$ or norepinephrine treatments) were maintained for $24 \mathrm{~h}$ in control, hypothyroid medium, or in a medium depleted of most growth factors present in the serum. Cells were then treated with $4 \mathrm{nmol} / \mathrm{l}$ insulin for $24 \mathrm{~h}$, or with $10 \mu \mathrm{mol} / \mathrm{l}$ norepinephrine or $10 \mathrm{nmol} / \mathrm{l} \mathrm{T}_{3}$ for the last $4 \mathrm{~h}$, so that all samples were collected at day 8 of culture. As shown in Fig. 6A, norepinephrine clearly stimulated GAPDH mRNA in control medium, its effect being similar to the induction achieved by insulin. When both hormones were added together, no increase in GAPDH mRNA levels was observed (lane 4).

In the absence of thyroid hormones (hypothyroid medium), the basal levels of GAPDH mRNA were lower than in the control medium (lane 1 compared with lane 5 ), because of the positive effect of $\mathrm{T}_{3}$ on this gene. Insulin induction in the hypothyroid medium was as potent as in the control medium, but the action of norepinephrine was lower (lane 3 compared with lane 7 ), which may suggest a permissive effect of $\mathrm{T}_{3}$ on norepinephrine action. The addition of both insulin and norepinephrine slightly increased the induction obtained with insulin alone (compare lanes 6 and 8). This effect was better observed when cells were depleted of most growth factors present in the serum (depleted medium). As shown in Fig. 6B, the addition of norepinephrine enhanced the effect of insulin (compare lanes 2 and 4 ), but $\mathrm{T}_{3}$ treatment did not further increase this response. Again, insulin (lane 2) and $\mathrm{T}_{3}$ alone (lane 6) induced GAPDH mRNA levels, but the addition of both hormones did not modify the effect obtained with insulin alone. From these results, we conclude that maximal induction of GAPDH is achieved when insulin and norepinephrine are present together, which may suggest a co-operation between them. Concerning $\mathrm{T}_{3}$, the results shown do not suggest a co-operation of this hormone with either norepinephrine or insulin, but 

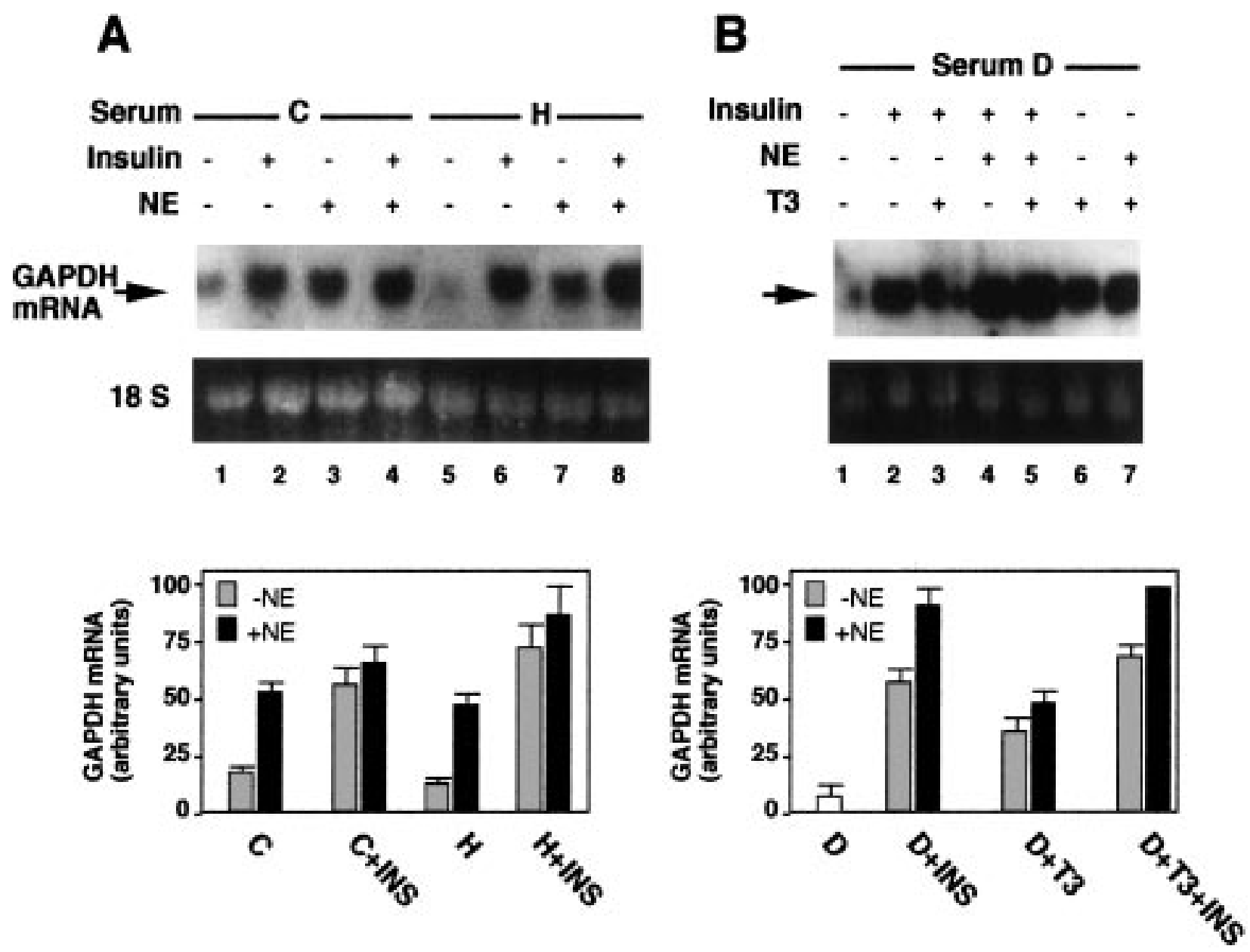

Figure 6 Effect of norepinephrine (NE) on GAPDH mRNA. Interaction among insulin (INS)-, norepinephrine- and $\mathrm{T}_{3}$ (T3)-mediated effects on GAPDH. Cells were cultured in control medium until day 6 (in the case of insulin) or day 7 (in the case of $T_{3}$ and norepinephrine). For the next $24 \mathrm{~h}$, they were grown in control $(\mathrm{C})$ or hypothyroid $(\mathrm{H})$ medium, or in a medium depleted of most growth factors $(\mathrm{D})$. (A) Representative Northern blot and its ethidium bromide control when cells were grown in C or H medium and treated with $4 \mathrm{nmol} / /$ insulin for $24 \mathrm{~h}$, or $10 \mu \mathrm{mol} / \mathrm{l}$ norepinephrine for the last $4 \mathrm{~h}$. (B) Corresponding Northern blot when the same experimental approach was performed in cells depleted of most growth factors (D serum). The graphs represent the quantitation of GAPDH mRNA by densitometer analysis from three independent autoradiograms and the data are given as means \pm S.D.

rather reflect that thyroid hormones regulate GAPDH through a different pathway.

\section{cAMP analogs increase GAPDH mRNA levels}

As the effects of norepinephrine are mainly mediated through stimulation of adrenergic receptors, followed by an increase in intracellular cAMP concentrations $(17,26,37,41)$ we tested whether norepinephrine increases GAPDH mRNA through this second messenger, using the cAMP analog, 8 -Br-cAMP $(1 \mathrm{mmol} / \mathrm{l})$. Cells at day 8 after seeding were treated with $1 \mathrm{mmol} / \mathrm{l}$ 8 -Br-cAMP and a time-course experiment was performed. As shown in Fig. 7, GAPDH mRNA levels increased two- to threefold in the presence of this compound, with a maximum effect observed after $24 \mathrm{~h}$ of incubation. The same data were obtained when cells were treated with forskolin (data not shown). We conclude that an increase in intracellular levels of cAMP in our system positively regulated the expression of the GAPDH gene.

\section{Retinoic acid decreases GAPDH mRNA levels in brown adipocytes}

Retinoic acid is involved in a wide range of functions in the body. Its role in adipose differentiation is controversial and seems to be strictly dependent on the dose used $(42,43)$. In this tissue, retinoic acid regulates the expression of thermogenic genes such as $\operatorname{UCP}(20,44)$, and lipogenesis-related proteins such as malic enzyme (45), or Spot 14 (34), either positively or negatively. The effect of retinoic acid on GAPDH mRNA was tested in cells growing either in control or hypothyroid medium 


\section{8-Br-cAMP}

$$
\text { Time (h) }
$$

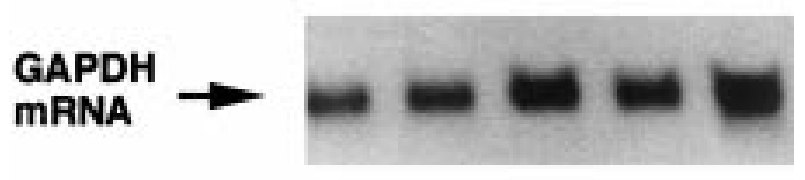

$18 S$
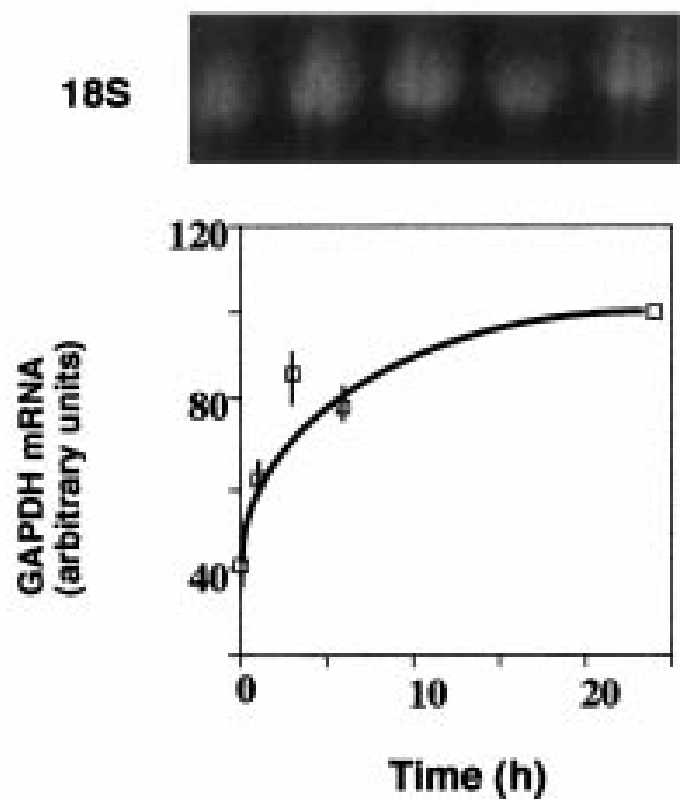

Figure 7 Effect of 8-Br-cAMP on GAPDH transcript. Time course of GAPDH mRNA induction by 8-Br-cAMP. Cells were grown in control medium until day 8 and then treated with $1 \mathrm{mmol} / \mathrm{l} 8-\mathrm{Br}$-cAMP. Total RNA was obtained after 1, 3, 6 and $24 \mathrm{~h}$ and hybridized with GAPDH probe. A representative Northern blot and the corresponding ethidium bromide staining are shown. Quantitation by densitometer analysis from three independent experiments is represented. Data are given as means \pm S.D.

for $48 \mathrm{~h}$ in the presence or absence of $10 \mathrm{nmol} / \mathrm{l} \mathrm{T}_{3}$, all-trans retinoic acid, or both, at the doses indicated in Fig. 8. As shown in this figure, retinoic acid slightly inhibited GAPDH transcript (lanes 5-8) only in high doses, this effect being better observed in the absence of thyroid hormones (hypothyroid medium) (lane 1 compared with lane 3 ). When retinoic acid was added together with $\mathrm{T}_{3}$, the induction observed with the latter was only weakly inhibited by the retinoic acid (lane 2 compared with lane 4).

\section{Discussion}

GAPDH has been traditionally considered as a housekeeping gene, the levels of which would remain stable under different manipulations. Despite its widespread use as an internal control, GAPDH gene expression varies in different situations (3-9). This enzyme has a key role in adipocytes, in which glycolysis is an important metabolic pathway for providing lipogenic substrates. As demonstrated in differentiating white adipocytes (10) and in adipose tissue derived from genetically obese rats $(11,30)$, upregulation of GAPDH parallels the acquisition of the full lipogenic phenotype. In this report, we have studied GAPDH regulation in brown preadipocytes. When grown under specific conditions, these cells undergo both thermogenic and lipogenic differentiation programs $(24,26)$ and become responsive to hormones that regulate lipid metabolism.

As expected, GAPDH transcript increased in parallel with differentiation of the cells, mainly between days 4 and 6 , when they had not yet acquired full lipogenic capacity. In later stages, GAPDH mRNA levels remained unaltered unless the cells received a lipogenic or lipolytic stimulus. This early onset of GAPDH has been reported in white adipose tissue (46) and, in BAT, precedes the activation of other lipogenesis-related enzymes such as malic enzyme (33) or Spot 14 (34). As the regulation of GAPDH transcript is seen better during lipogenic differentiation (days 5-9), the effect of the main regulators of the tissue was examined in that period.

Insulin, acting through its own receptors, upregulated GAPDH mRNA levels on whichever culture day it was examined. It stabilized GAPDH transcript, and probably stimulated the transcriptional rate of the gene. This latter mechanism of action has been reported in adipocyte (8) and non-adipocyte (36) cell lines, and two different insulin response elements have been found in the human gene promoter (32). When cycloheximide was used, the inhibitor blocked the induction observed with insulin, suggesting that short-lived proteins could be required for either the transcription or the stabilization process.

In addition to insulin, GAPDH appears to be a target for $\mathrm{T}_{3}$, norepinephrine and retinoic acid in these cells. The role of $\mathrm{T}_{3}$ in BAT is well known $(18,47)$ : it affects UCP 1 gene expression (35), and interacts with norepinephrine and retinoic acid $(20,35)$. In this report, we have shown for the first time that $\mathrm{T}_{3}$ increases GAPDH mRNA levels in differentiating brown adipocytes. Another lipogenic gene, malic enzyme $(M E)$, is subjected to a similar regulation by $\mathrm{T}_{3}$ in this tissue (33). The mechanism used by $\mathrm{T}_{3}$ for regulating both genes is also very similar, as $\mathrm{T}_{3}$ stabilizes GAPDH mRNA and requires de novo protein synthesis, as was the case for malic enzyme. However, the existence of a thyroid hormone response element - exhaustively described for $M E$ (48) - in the rat GAPDH promoter cannot be excluded.

Norepinephrine, considered to be the main physiological regulator of BAT, affects proliferation (49) and differentiation $(17,26)$ of brown preadipocytes. We have shown here that norepinephrine, probably through cAMP, upregulates GAPDH mRNA levels in differentiating brown adipocytes. This finding could be controversial in light of the well known role of norepinephrine as activator of lipolysis: two lipogenesis-related proteins, 


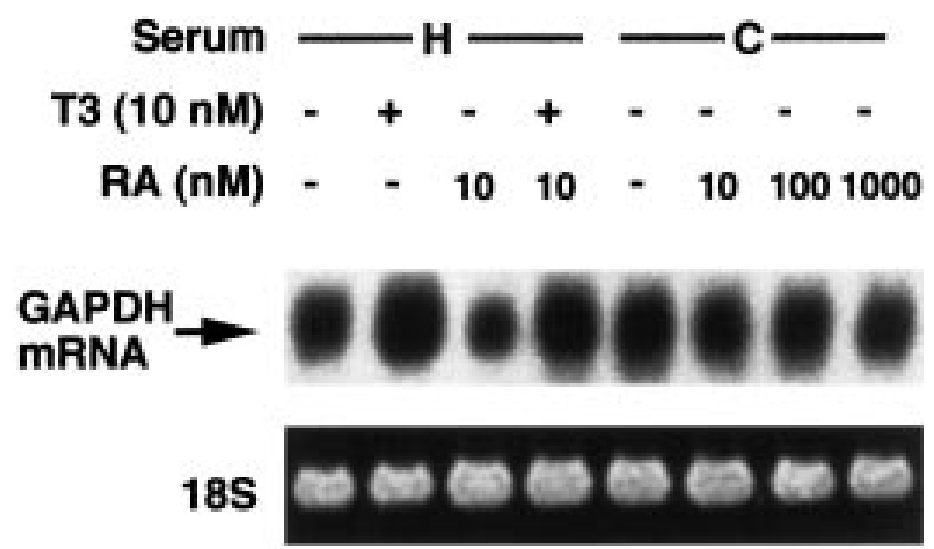

Figure 8 Effect of retinoic acid (RA) on basal and $\mathrm{T}_{3}$ (T3)-induced GAPDH mRNA levels. Cells on day 6 after seeding were cultured in control (C) medium and treated with increasing amounts $(10,100$ or $1000 \mathrm{nmol} / \mathrm{l})$ of retinoic acid (RA), or were grown in hypothyroid $(\mathrm{H})$ medium for $24 \mathrm{~h}$ and then treated with $10 \mathrm{nmol} / / \mathrm{T}_{3}, 10 \mathrm{nmol} / \mathrm{l}$ alltrans retinoic acid, or both. All treatments lasted $48 \mathrm{~h}$, after which total RNA was isolated and GAPDH mRNA levels analyzed by Northern blot, and quantitated by scanner densitometry. Data are given as means \pm s.D. from three independent experiments.

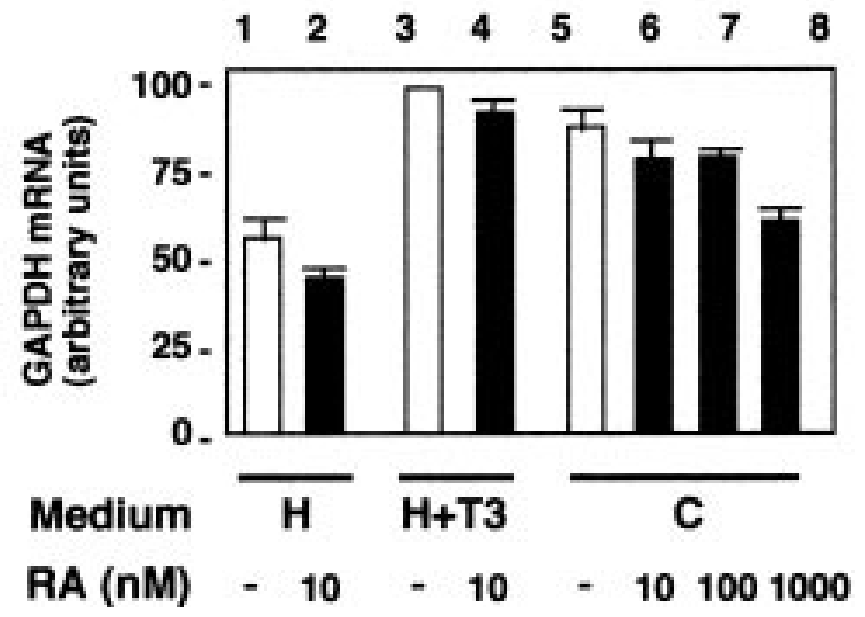

malic enzyme (45) and Spot 14 (34), are downregulated by norepinephrine in this system. However, Bianco et al. (50) have recently demonstrated that norepinephrine also stimulates lipogenesis in brown adipocytes, to allow the cell to recover its fat depots after heat generation by lipolysis.

When norepinephrine, insulin and $\mathrm{T}_{3}$ are studied together, a slight loss of induction by norepinephrine is observed in the absence of thyroid hormones. This difference, although modest, could reflect a permissive role of $\mathrm{T}_{3}$ on norepinephrine action. Interestingly, the combined action of insulin and norepinephrine suggests a co-operation between both hormones that should be studied further. This effect is specific for GAPDH and not a consequence of the tissue used, as other lipogenesis-related enzymes exhibit an opposite regulation (45).

Finally, the action of all-trans retinoic acid on GAPDH transcript was examined in this system. In brown adipocytes, retinoids regulate UCP gene expression (20, 44) and influence cell differentiation (51). As has been reported for $M E$ (45), all-trans retinoic acid downregulates GAPDH mRNA levels in high doses.

In summary, we have shown that GAPDH mRNA expression is regulated by multiple factors in differentiating brown adipocytes: it increases with the acquisition of the fully differentiated phenotype, and is stimulated by the three major regulators of BAT function - insulin, $\mathrm{T}_{3}$, and norepinephrine. This multifactorial regulation probably provides the cell with another means by which to control lipogenesis, and provides a strong basis on which to study the molecular mechanisms that underlie this regulation.

\section{Acknowledgements}

We thank Dr Juan A Velasco for critical reading of this manuscript. We are indebted to Dr Maria Alexander (Massachusetts General Hospital, Boston MA, USA) for the GAPDH cDNA.

This work was supported by Grants (PM97-0065) to P S and (PB95-0097) to M O from DGICYT (Spain). IB has a fellowship from Comunidad Autónoma de Madrid (Spain).

IB and B B contributed equally to this work.

\section{References}

1 Sirover MA. Emerging new functions of the glycolytic protein, glyceraldehyde-3-phosphate dehydrogenase, in mammalian cells. Life Science 199658 2271-2277. 
2 Graven KK, Troxler RF, Kornfeld H, Panchenko MV \& Farber HW Regulation of endothelial cell glyceraldehyde-3-phosphate dehydrogenase expression by hypoxia. Journal of Biological Chemistry $199426924446-24453$.

3 Mansur NR, Meyer-Siegler K, Wurzer JC \& Sirover MA. Cell cycle regulation of the glyceraldehyde-3-phosphate dehydrogenase/ uracil DNA glycosylase gene in normal human cells. Nucleic Acids Research 199321 993-998.

4 McNully SE \& Toscano WA. Transcriptional regulation of glyceraldehyde-3-phosphate dehydrogenase by 2,3,7,8-tetrachlorodibenzo-p-dioxin. Biochemical and Biophysical Research Communications $1995212165-171$.

5 Vincent S, Marty L \& Fort P. S26 ribosomal protein RNA: an invariant control for gene regulation experiments in eucaryotic cells and tissues. Nucleic Acids Research 1993211498.

6 Desprez PY, Pujol D \& Saez S. Glyceraldehyde-3-phosphate dehydrogenase (GAPDH, E.C. 1.2.12.) gene expression in two malignant human mammary epithelial cell lines: BT-20 and MCF7. Regulation of gene expression by 1,25-dihydroxyvitamin D3 (1,25-(OH $)_{2}$ D3. Cancer Letters 199264 219-224.

7 Roche E, Assimacopoulos-Jeannet F, Witters LA, Perruchoud B, Yaney G, Corkey B et al. Induction by glucose of genes coding for glycolytic enzymes in a pancreatic $\beta$-cell line (INS-1). Journal of Biological Chemistry $19972723091-3098$.

8 Alexander M, Curtis G, Avruch J \& Goodman HM. Insulin regulation of protein biosynthesis in differentiated 3T3 adipocytes. Journal of Biological Chemistry 198526011978 11985.

9 Nasrin N, Buggs C, Kong XF, Carnazza J, Goebl M \& AlexanderBridges M. DNA-binding properties of the product of the testisdetermining gene and a related protein. Nature 1991354 317-332.

10 Spiegelman BM \& Green H. Control of specific protein biosynthesis during the adipose conversion of 3T3 cells. Journal of Biological Chemistry $19802558811-8818$.

11 Rolland V, Dugail I, Le Liepvre X \& Lavau M. Evidence of increased glyceraldehyde-3-phosphate dehydrogenase and fatty acid synthetase promoter activities in transiently transfected adipocytes from genetically obese rats. Journal of Biological Chemistry $19952701102-1106$.

12 Ricquier D \& Bouillaud F. The brown adipose tissue mitochondrial uncoupling protein. In Brown Adipose Tissue, pp 86-104. Eds P Trayhurn \& DG Nicholls. London: Edward Arnold Publishers, 1986.

13 Fleury C, Neverova M, Collins S, Raimbault S, Champigny O, Levi MC et al. Uncoupling protein-2: a novel gene linked to obesity and hyperinsulinemia. Nature Genetics 199715 269-272.

14 Boss O, Samec S, Paoloni GA, Rossier C, Dulloo A, Seydoux J et al. Uncoupling protein-3: a new member of the mitochondrial carrier family with tissue-specific expression. FEBS Letters 1997 408 39-42.

15 Gong D-W, He Y, Karas M \& Reitman M. Uncoupling protein-3 is a mediator of thermogenesis regulated by thyroid hormone, $\beta 3$ adrenergic agonists, and leptin. Journal of Biological Chemistry $199727224129-24132$.

16 Himms-Hagen J. Brown adipose tissue metabolism and thermogenesis. Annual Review of Nutrition $1985569-94$.

17 Cannon B \& Nedergaad J. Adrenergic regulation of brown adipocyte differentiation. Biochemical Society Transactions 1996 24 407-412.

18 Silva JE. Thyroid hormone control of thermogenesis and energy balance. Thyroid $19955481-492$.

19 McCormack JG. The regulation of fatty acid synthesis in brown adipose tissue by insulin. Progess in Lipid Research 198221195 223.

20 Rabelo R, Reyes C, Schifman A \& Silva JE. A complex retinoic acid response element in the uncoupling protein gene defines a novel role for retinoids in thermogenesis. Endocrinology 1996137 3488-3496.

21 Himms-Hagen J. Brown adipose tissue thermogenesis: interdisciplinary studies. FASEB Journal 19904 2890-2898.
22 Himms-Hagen J. Brown adipose tissue metabolism. In Obesity, pp 15-34. Eds P Bjorntorp \& BN Brodoff. New York: Lippincott, 1992.

23 Lowell BB, S-Susulic V, Hamann A, Lawitts JA, Himms-Hagen J, Boyer BB et al. Development of obesity in transgenic mice after genetic ablation of brown adipose tissue. Nature $1993366740-$ 742.

24 Néchad M, Kuusela P, Carneheim C, Björntorp P, Nedergaad J \& Cannon B. Development of brown fat cells in monolayer culture. Experimental Cell Research 1983149 105-118.

25 Silva JE \& Rabelo R. Regulation of the uncoupling protein gene expression. European Journal of Endocrinology $1997136251-$ 264.

26 Rehmark S, Néchad M, Herron D, Cannon B \& Nedergaad J. $\alpha$ and $\beta$ - adrenergic induction of the expression of the uncoupling protein thermogenin in brown adipocytes differentiated in culture. Journal of Biological Chemistry 1990265 16464-16471.

27 Samuels HH, Stanley F \& Casanova J. Depletion of L-3,5,3'triiodothyronine and L-thyroxine in euthyroid calf serum for use in cell culture studies of the action of thyroid hormone. Endocrinology 1979105 80-85.

28 Herron D, Néchad M, Rehmark S, Nelson BD, Nedergaad J \& Cannon B. Effects of cholera toxin on gene expression in brown preadipocytes differentiating in culture. American Journal of Physiology 1989257 C920-C925.

29 Maniatis T, Fritsch EF \& Sambrook J. In Molecular Cloning - A Laboratory Manual. Cold Spring Harbor: Cold Spring Harbor Laboratory, 1982.

30 Dugail I, Quignard-Boulangé A, Le Liepvre X, Ardouin B \& Lavau M. Gene expression of lipid storage-related enzymes in adipose tissue of the genetically obese Zucker rat. Biochemical Journal $1992281607-611$.

31 Kormanec J, Lempel'ova A, Novakova R, Rezuchova, B \& Homerova D. Expression of the Streptomyces aureofaciens glyceraldehyde-3-phosphate dehydrogenase gene (gap) is developmentally regulated and induced by glucose. Microbiology 1997143 3555-3561.

32 Alexander MC, Lomanto M, Nasrin N \& Ramadka C. Insulin stimulates glyceraldehyde-3-phosphate dehydrogenase gene expression through cis-acting DNA sequences. Proceedings of the National Academy of Sciences of the USA $1988855092-5096$.

33 García-Jiménez C, Hernández A, Obregón MJ \& Santisteban P. Malic enzyme gene expression in differentiating brown adipocytes: regulation by insulin and triiodothyronine. Endocrinology $19931321537-1543$.

34 Pérez-Castillo A. Hernández A. Pipaón C. Santos A \& Obregón MJ. Multiple regulation of $\mathrm{S} 14$ gene expression during brown fat differentiation. Endocrinology 1993133 545-552.

35 Rabelo R, Schifman A, Rubio A, Sheng X \& Silva JE. Delineation of thyroid hormone responsive sequences within a critical enhancer in the rat uncoupling protein gene. Endocrinology 1995136 1003-1013.

36 Ortiz L, Zannini M, Di Lauro R \& Santisteban P. Transcriptional control of the fork-head thyroid transcription factor TTF-2 by thyrotropin, insulin, and insulin-like growth factor I. Journal of Biological Chemistry $199727223334-23339$.

37 Bianco AC, Kieffer JD \& Silva JE. Adenosine 3', 5'-monophosphate and thyroid hormone control of uncoupling protein messenger ribonucleic acid in freshly dispersed brown adipocytes. Endocrinology $19921302625-2633$.

38 Rubio A, Raasmaja A, Maia AL, Kim KR \& Silva JE. Effects of thyroid hormone on norepinephrine signaling in brown adipose tissue. I. Beta 1- and beta 2-adrenergic receptors and cyclic adenosine 3',5'-monophosphate generation. Endocrinology 1995 $1363267-3276$.

39 Rubio A, Raasmaja A \& Silva JE. Thyroid hormone and norepinephrine signaling in brown adipose tissue. II: Differential effects of thyroid hormone on beta 3-adrenergic receptors in brown and white adipose tissue. Endocrinology 19951363277 3284. 
40 El Hadri K, Charon C, Pairault J, Hauguel-de Mouzon S, QuignardBoulangé A \& Fève B. Down-regulation of $\beta 3$-adrenergic receptor expression in rat adipose tissue during the fasted/fed transition: evidence for a role of insulin. Biochemical Journal 1997323359 364.

41 Ma SWY \& Foster DO. Potentiation of in vivo thermogenesis in rat brown adipose tissue by stimulation of alpha 1-adrenoreceptors is associated with increased release of cyclic AMP. Canadian Journal of Physiology and Pharmacology 198462 943-948.

42 Kamei Y, Kawada T, Mizukami J \& Sugimoto E. The prevention of adipose differentiation of 3T3-L1 cells caused by retinoic acid is elicited through retinoic acid receptor alpha. Life Science 199455 PL307-312.

43 Safonova I, Darimont C, Amri EZ, Grimaldi P, Ailhaud G, Reichert U et al. Retinoids are positive effectors of adipose cell differentiation Molecular and Cellular Endocrinology 1994104 201-211.

44 Puigserver P, Vázquez F, Bonet ML, Picó C \& Palou A. In vivo and in vitro induction of brown adipocyte uncoupling protein (thermogenin) by retinoic acid. Biochemical Journal $1996317827-833$.

45 Hernández A, García-Jiménez C, Santisteban P \& Obregón, MJ. Regulation of malic-enzyme-gene expression by cAMP and retinoic acid in differentiating brown adipocytes. European Journal of Biochemistry 1993215 285-290.

46 Dugail I, Quignard-Boulange A, Bazin R, Le Liepvre X \& Lavau M. Adipose-tissue-specific increase in glyceraldehyde-3-phosphate dehydrogenase activity and mRNA amounts in suckling pre-obese
Zucker rats. Effect of weaning. Biochemical Journal 1988254 483-487.

47 Bianco AC \& Silva JE. Intracellular conversion of thyroxine to triiodothyronine is required for the optimal thermogenic function of brown adipose tissue. Journal of Clinical Investigation 198779 295-300.

48 Petty KJ, Desvergne B, Mitshuhashi T \& Nikodem V. Identification of a thyroid hormone response element in the malic enzyme gene. Journal of Biological Chemistry 1990265 7395-7400.

49 Garcia B \& Obregon MJ. Norepinephrine potentiates the mitogenic effect of growth factors in quiescent brown preadipocytes: relationship with uncoupling protein messenger ribonucleic acid expression. Endocrinology 1997138 4227-4233.

50 Bianco AC, Carvalho SD, Carvalho CRF, Rabelo R \& Moriscot AS. Thyroxine 5'-deiodination mediates norepinephrine induced lipogenesis in dispersed brown adipocytes. Endocrinology 1998 $139571-578$.

51 Safonova I, Reichert U, Shroot B, Ailhaud G \& Grimaldi P. Fatty acids and retinoids act synergistically on adipose cell differentiation. Biochemical and Biophysical Research Communications 1994 204 498-504

Received 8 February 1999

Accepted 27 April 1999 